\title{
Het jonge brein met mogelijkheden
}

\author{
Citation for published version (APA):
}

Vermeulen, J. (2017). Het jonge brein met mogelijkheden. Maastricht University. https://doi.org/10.26481/spe.20171027jv

Document status and date:

Published: 27/10/2017

DOI:

10.26481/spe.20171027jv

Document Version:

Publisher's PDF, also known as Version of record

Document license:

Unspecified

\section{Please check the document version of this publication:}

- A submitted manuscript is the version of the article upon submission and before peer-review. There can be important differences between the submitted version and the official published version of record.

People interested in the research are advised to contact the author for the final version of the publication, or visit the DOI to the publisher's website.

- The final author version and the galley proof are versions of the publication after peer review.

- The final published version features the final layout of the paper including the volume, issue and page numbers.

Link to publication

\footnotetext{
General rights rights.

- You may freely distribute the URL identifying the publication in the public portal. please follow below link for the End User Agreement:

www.umlib.nl/taverne-license

Take down policy

If you believe that this document breaches copyright please contact us at:

repository@maastrichtuniversity.nl

providing details and we will investigate your claim.
}

Copyright and moral rights for the publications made accessible in the public portal are retained by the authors and/or other copyright owners and it is a condition of accessing publications that users recognise and abide by the legal requirements associated with these

- Users may download and print one copy of any publication from the public portal for the purpose of private study or research.

- You may not further distribute the material or use it for any profit-making activity or commercial gain

If the publication is distributed under the terms of Article $25 \mathrm{fa}$ of the Dutch Copyright Act, indicated by the "Taverne" license above, 
Oratie 27 oktober 2017

Het jonge brein met mogelijkheden

Welkom

Rector magnificus, collegae, familie en vrienden,

Aan het begin van mijn rede neem ik u mee naar mijn spreekkamer.

Esther zit in een rolstoel en kan niet spreken. Ze kan niet lopen. Dan, na ruim 10 seconden, klinkt uit haar computer "goede morgen dokter Vermeulen". Er verschijnt een glimlach op haar gezicht. Als haar moeder aangeeft dat er problemen zijn beweegt Esther onrustig en stuurt haar computer aan: "bemoei je met je eigen zaken" klinkt het op heldere toon. Esther had dit namelijk best zelf willen vertellen op haar manier.

In zal u meenemen hoe een patiënt als Esther je moet inspireren haar conditie te verbeteren en haar mogelijkheden die ze heeft ten volle te benutten.

In mijn rede zal de patiënt met zijn of haar mogelijkheden centraal staan en daarmee de ouders en begeleiders ook. Als vertegenwoordigers van onze patiënten nemen zij een belangrijke rol in.

In het boek "schaduwkind" van de schrijver Thomese, worden wij meegevoerd in de ervaring van een ouder die zijn pasgeboren kind verliest.

Zijn beschrijving geeft een impressie van de delicate positie waarin ouders en zorgverleners zich bevinden. En toont de complexiteit van communicatie tussen ouders en zorgverleners bij ernstige zieke jonge kinderen.

In de kinderneurologie hebben wij te maken met een kwetsbare groep kinderen, waaronder te vroeg geboren kinderen, prematuren genaamd.

Prematuur geboren kinderen worden steeds vroeger geboren en hebben onderontwikkelde organen waaronder ook de hersenen. Vanaf de $24^{\mathrm{e}}$ week van de zwangerschap kunnen kinderen in leven worden gehouden. De mortaliteit van deze kinderen is nog altijd hoog, maar geleidelijk verbeterend.

Deze kinderen hebben helaas veel problemen wat betreft de ontwikkeling. Hersenschade in de vorm van witte stof schade en bloedingen komt regelmatig voor bij deze kinderen. Ik wil stil staan bij de witte stof. De hersencellen, die we neuronen noemen, hebben uitlopers, zogenaamde axonen, die signalen aan de rest van het lichaam doorgeven. De axonen lopen als kabels door hersenen.

Bij de geboorte zijn deze axonen aanwezig maar ontbreekt het isolatie materiaal myeline grotendeels. Speciale cellen, de oligodendrocyten maken in de eerste jaren myeline aan. Helaas zijn deze oligodendrocyten in ontwikkeling heel kwetsbaar onder andere voor bloedingen en infectie.

Nu gaan even terug naar de neonatologie afdeling. Samen met de neonatoloog bespreken we met ouders dat hun kind een hersenbloeding heeft. 
De vraag van de ouder:

$U$ ziet dus een hersenbloeding, wat kunt u er aan doen en wat betekent het voor de toekomst?

Het is belangrijk voor de behandeling om in kaart te brengen hoe ernstig een hersenbloeding is.

Met behulp van schedelecho (ultrageluid) en MRI kunnen we de bloeding zichtbaar maken.

Maar we willen meer. In de komende jaren gaan we samen met de neuroradiologen en fysici onderzoeken hoe we nog beter de schade in de hersenen zichtbaar kunnen maken. Een van die technieken is diffusie tensor imaging. Hierbij kijken we met de MRI naar de richting van bewegen van water. Water beweegt makkelijk in de richting van zenuwbanen in de hersenen. Hierdoor kunnen we hele fraaie beelden maken alsof we de vezels zelf zien. Met nieuwere technieken hopen we nog een beter beeld van de problemen bij deze pasgeborenen te krijgen. En als het ware een behandeling op maat te kunnen maken.

Een andere bedreiging voor de pasgeborene zijn infecties en in het bijzonder voor de te vroeggeboren pasgeborene. Het voorkomen van infecties lijkt heel belangrijk. Daarnaast lijkt van belang de infecties eerder en gerichter met antibiotica te behandelen. Maar de behandeling van deze jonge kinderen met antibiotica heeft ook nadelen door het verminderen van onze gewone bacteriën. Uit een recent overzichtsartikel blijkt dat herintroduceren van gewone bacteriën een gunstig effect kan hebben bij deze prematuur geboren kinderen.

Niet alleen de infectie zelf kan schadelijk zijn, maar ook stoffen die vrijkomen bij de ontstekingsreactie.

De vraag is of we deze stoffen kunnen verwijderen of kunnen blokkeren.

Experimenteel wordt in Maastricht gewerkt aan interventies die deze ontstekingsreactie kunnen verminderen. Bij schapen is aangetoond dat speciale stamcellen, zogenaamde mesenchymale stamcellen, de schade aan hersenen door infectie kunnen verminderen. Bij deze behandeling gaan de stamcellen niet de hersencellen vervangen maar leveren de stamcellen nuttige neuroprotective, dus beschermende, stoffen. In de komende jaren gaan we samen met de onderzoekers van de afdeling kindergeneeskunde effecten van deze experimentele behandelingen bestuderen. Beeldvorming van de hersenen met MRI, magnetische resonantie, speelt hierbij een grote rol. Speciale MRI scanners met hele sterke magneetvelden kunnen hierbij helpen de kleinste details zichtbaar te maken. In Maastricht hebben we beschikking over scanners met zo'n heel sterk magneet veld en hopen we in de komende jaren antwoorden te genereren.

Op deze manier hopen we een vertaling te maken naar de klinische situatie. Wij hopen zo deze experimentele behandelingen naar de kliniek te kunnen verplaatsen om zo de conditie van deze kwetsbare kinderen te kunnen verbeteren.

De nachtmerrie van iedere aanstaande ouder. Het gaat mis rond de geboorte.

Bij een kindje in de baarmoeder daalt de hartslag snel. De gynaecoloog start een spoed keizerssnede en het kind wordt geboren zonder hartslag en wordt gereanimeerd. Het kind wordt beademd en naar de intensive care unit van de neonatologie gebracht. 
In het eerste gesprek op de afdeling stellen de ouders de volgende vraag:

"Dokter wij willen graag van u weten welke problemen ons kind gaat krijgen, wij willen geen kasplantje."

Met verbeterende gezondheidszorg hoop je dat bepaalde problemen niet meer voorkomen. Een groot probleem vormt het acute zuurstof gebrek rond de geboorte, ook wel asfyxie genoemd. Door dit zuurstof gebrek komen veel organen in de problemen, nieren, lever, hart maar ook de hersenen. Deze hersenschade kunnen we goed in beeld brengen met MRI. De witte plekken tonen de gebieden waar een probleem mee is.

Op dit moment weten we dat koeling, in een zogenaamd koelpak, tot 33,5 graad Celsius een zeer effectieve methode is om sterfte te verminderen en hersenschade te verminderen.

De vraag is ook hoe goed wij met de MRI de uitkomst van een kindje kunnen voorspellen. Met de getoonde MRI technieken kunnen we in meer dan $80 \%$ van de kinderen een goede voorspelling doen.

Helaas zijn in de praktijk onze voorspellingen niet altijd accuraat. Dat is in de praktijk een groot probleem. De vraag dient zich aan of er MRI technieken zijn die de voorspellende waarde van de MRI kunnen verbeteren.

Allereerst kunnen we kijken hoe de hersenen functioneren. We weten dat de hersenen als een netwerk functioneren. Met behulp van elektro-encefalografie, een techniek waarmee we de elektrische activiteit van de hersenen kunnen registreren of met behulp van MRI kunnen we deze netwerken in de hersenen in beeld brengen. De waarde hiervan zullen we in de komende jaren verder onderzoeken en kijken of we het kunnen toevoegen aan ons standaard diagnostiek.

De ontwikkeling van kinderen verloopt volgens bekende mijlpalen. Kinderen met een hersenbeschadiging hebben een anders verlopende ontwikkeling, trager en ook met een minder goede functie.

De hersenbeschadiging leidt tot een andere manier van bewegen en daar kennen we drie type stoornissen: Spasticiteit, stijvere spieren en hoge reflexen. Dystonie, waarbij kinderen niet gecontroleerde onwillekeurige bewegingen hebben en ataxie, waarbij de sturing van beweging een groot probleem is.

De aandoening waarbij kinderen met een hersenbeschadiging een bewegingsstoornis hebben noemen we cerebrale parese.

De ernst van de ontwikkelingsproblemen kunnen we het beste duidelijk maken aan de hand van indeling van de beperking in het lopen bij kinderen met een cerebrale parese.

Voor de ontwikkeling van de motoriek is de piramide baan een heel erg belangrijke structuur. Als we nu kunnen aantonen dat de piramide baan afwijkend is, kunnen een afwijkende motorische ontwikkeling goed voorspellen.

Bij pasgeborenen kan een herseninfarct optreden in een van beide hersenhelften. En inderdaad kunnen we op MRI onderzoek van de hersenen bij een pasgeborene met zo'n herseninfarct eenzijdige afwijkingen aan de piramide baan aantonen, die voorspellend zijn voor motorische problemen. En kunnen we daar dan ook wat aan doen? Er lijken inderdaad behandelingen te zijn die de schade mogelijk zouden kunnen beperken. 
In experimentele setting lijkt het hormoon erythropoietine, ook wel EPO genoemd, een potentieel middel om schade te beperken. De afdeling neonatologie in Utrecht heeft daar recent een studie mee gestart.

Mesenchymale stamcellen kunnen door afgifte van schade beperkende stoffen mogelijk ook een plaats krijgen bij de behandeling van het herseninfarct bij de pasgeborene.

De vraag is nu, wat kunnen we doen als de schade er eenmaal is. We kunnen proberen gebruik te maken van de plasticiteit van de hersenen door heel gericht te oefenen bij jonge kinderen. Dit is een veelbelovende aanpak, en voor grotere kinderen weten we dat deze aanpak van stimulatie helpt. Bij kleine kinderen, jonger dan een jaar is het effect van stimulatie nog niet bekend.

Tot nu toe hebben we vooral gekeken naar het bewegen en was de stimulatie ook gericht op verbeteren van het bewegen. Maar gevoelsstoornissen blijken bij veel van deze kinderen voor te komen. Gevoelsstoornissen hebben mogelijk een negatief effect op de ontwikkeling van het bewegen. Alleen is daar weinig over bekend. Daarom zullen we de komende jaren samen met collega's van Adelante veel aandacht besteden aan deze problemen van het gevoel. En zullen we onderzoeken of met extra aandacht voor het gevoel de mogelijkheden voor deze kinderen kunnen vergroten.

Het bewegen, waaronder het lopen is bij veel kinderen met cerebrale parese een probleem. Het onderzoek naar bewegen bij kinderen met cerebrale parese vindt plaats binnen onze speciale focusgroep, de "specialty bewegen". Dit is een multidisciplinaire groep met clinici en basale wetenschappers. Deze brede kritische expertise groep is het platform voor nieuw te ontwikkelen onderzoek naar bewegen binnen het MUMC+. In Maastricht beschikken we over de meest geavanceerde opstellingen voor het bestuderen van het lopen, de gangbeeld laboratoria. De analyses hiervoor zijn complex. Samenwerking tussen clinici, de basale wetenschappers en technici is van cruciaal belang om het optimale rendement uit deze prachtige apparatuur te halen.

Deze infrastructuur is ook belangrijk om effecten van behandeling te bestuderen. Ik zal $\mathrm{u}$ daar een voorbeeld van schetsen.

Een van de problemen bij kinderen met een eenzijdige of unilaterale spastische cerebrale parese, is behalve de stijfheid de verminderde kracht van de voetheffers.

Hierdoor worden kinderen sneller vermoeid en struikelen ze vaker.

In de komende jaren gaan we de effecten van neuromodulatie bestuderen. Hierbij worden de voetheffers gestimuleerd met een elektrische prikkel. We hopen zo duidelijkheid te krijgen wat de voor en nadelen zijn in het dagelijks leven.

Behalve minder kracht is ook de aansturing van bewegingen een probleem. Stelt u zich voor: $\mathrm{U}$ steekt uw hand uit om uw jas te pakken. Daarbij heeft $u$ het doel uw hand te bewegen naar een bepaalde positie zodat $u$ uw jas kunt pakken. Wat u niet doet is dat $u$ bewust alle betrokken spieren apart aanstuurt om deze beweging in gang te zetten. $U$ maakt gebruik van een bewegingsroutine die opgeslagen is in het ruggenmerg. Ook voor lopen maakt u gebruik van dergelijke bewegingsroutines. Bij kinderen met cerebrale parese zijn deze routines verstoord. In de komende jaren willen wij samen met onderzoekers uit Amsterdam de 
ontwikkeling van deze verstoorde routines beter leren begrijpen en uiteindelijk deze routines te verbeteren.

Een van de grote uitdagingen ligt in het beter beschikbaar krijgen van data uit een complexe analyse. Ons nieuwe gangbeeld systeem met virtuele omgeving levert veel data op. We spreken dan van zogenaamde Big Data. Met gebruik van zelflerende algoritmes zullen we proberen deze classificatie automatisch te laten plaatsvinden.

Bij kinderen met zuurstof gebrek rond de geboorte treedt naast beschadiging van de piramide baan ook vaak schade op aan de basale kernen en in mindere mate de hippocampus.

Dit specifieke patroon van hersenschade demonstreert de selectieve gevoeligheid van de jonge hersenen. We weten dat kinderen met schade aan de basale kernen vaak problemen van het bewegen ontwikkelen.

Deze bewegingsstoornis noemen de dyskinesie. Omdat het een stoornis is bij een ontwikkelend kind, noemen we dit diskinetische cerebrale parese.

Door deze bewegingsstoornis hebben kinderen moeite met zich verplaatsen en zitten. Soms is ook de verzorging van deze kinderen heel moeilijk. De mogelijkheden voor behandeling zijn helaas beperkt en vaak onvoldoende effectief. Om die reden zijn wij 5 jaar geleden gestart met een onderzoek naar de waarde van intrathecale baclofen voor de behandeling van diskinetische cerebrale parese. Baclofen is een medicijn dat spieren kan ontspannen via effecten op het ruggenmerg en op de hersenen. Komend jaar zullen we de effecten van deze behandeling bij deze kinderen kennen. Een van de struikelblokken bij studies naar dyskinesie is de manier waarop we de onrustige (diskinetische) bewegingen van de kinderen betrouwbaar kunnen beoordelen. Onderzoekers uit Leuven hebben recent een nieuwe schaal ontwikkeld die geschikt lijkt voor het doel, maar zeer arbeidsintensief is en daarmee lastig is in de dagelijkse praktijk. Om die reden gaan we met onderzoekers uit Aken, Leuven en Amsterdam kijken hoe we deze meting kunnen versnellen door gebruik te maken van nieuwe bewegingstechnologie.

Een dergelijke analyse techniek zou voor kinderen met diskinetische cerebrale parese kunnen worden gebruikt maar ook bij volwassenen met bewegingsstoornissen.

De hierboven beschreven behandeling met intrathecale baclofen is ook een duidelijk voorbeeld van neuromodulatie. Een andere vorm van centrale neuromodulatie bij dyskinetische cerebrale parese is de diepe hersenstimulatie. Hierbij wordt door de neurochirurg een electrode in de hersenen gebracht. Daarbij proberen we verstoorde hersenactiviteit in een bepaald netwerk van de hersenen te verbeteren. Helaas wisselen de effecten van deze behandeling sterk per patiënt. Binnen ons diepe hersenstimulatie team bij kinderen is veel aandacht voor het beter beschrijven van onze patiënten ten einde op de lange duur een beter behandelvoorstel te doen. Maar ook biedt experimenteel onderzoek kansen om samen met de neurochirurgen te kijken of we andere methodes van hersenstimulatie nodig hebben bij deze kinderen om betere resultaten te krijgen. Door samenwerking met Amsterdam, Groningen en Nijmegen hopen wij een netwerk op te zetten voor alle kinderen in Nederland met dystonie.

Tot nu toe heb ik mij sterk gericht op de motorische vaardigheden. Voor het functioneren in het dagelijks leven (participatie) is bij deze kinderen het cognitief functioneren van zeer groot belang. 
Maar hier stuiten we op een probleem, namelijk het zeer frequent voorkomen van communicatie problemen bij kinderen met cerebrale parese.

In de meeste taal testen worden motorische vaardigheden van de kinderen gevraagd. Bijvoorbeeld, "zet het poppetje op de stoel". Door de bewegingsproblemen kunnen deze kinderen de normale testen vaak niet doen.

In 2008 is het plan geboren om een test voor deze kinderen te ontwikkelen. Deze test is inmiddels voltooid en heeft de naam C-BiLLT. Het is een prachtig instrument dat geschikt is om bij kinderen het taalbegrip te meten.

Kinderen kunnen met aanwijzen, of door te kijken een vraag beantwoorden uit deze test. Samen met het team uit Amsterdam gaan we de komende jaren onderzoeken hoe de taalontwikkeling bij deze kinderen verloopt en hoe we de taalontwikkeling uiteindelijk verder kunnen stimuleren. Uit onze eerste ervaringen is gebleken dat kinderen regelmatig meer mogelijkheden hebben dan de omgeving initieel verwachtte. Een belangrijke observatie bij kinderen met een ernstige vorm van cerebrale parese dat zij een sterke vertraging hebben in prikkelverwerking. Waar mensen zonder hersenbeschadiging binnen een halve seconde reageren kan de reactie van een kind of volwassene met cerebrale parese wel een tiental seconden bedragen.

Het is onduidelijk welke mechanismen hier precies aan ten grondslag liggen, maar het is een belangrijke factor om rekening mee te houden bij onderzoeksvragen en dagelijkse omgang met deze patiënten.

Wat we geleerd hebben is dat bij kinderen met cerebrale parese meer communicatie mogelijk is dan initieel gedacht. Daarom heeft de Amerikaanse cerebrale parese vereniging een campagne gestart om communicatie met deze kinderen met motorische beperkingen te verbeteren. "Just say $\mathrm{Hi}^{\prime}$ "... Het begin van communicatie .

In de kinderneurologie krijgen we regelmatig te maken met aanleg stoornissen van het zenuw stelsel. Een van de meest bekende aanlegstoornissen is de spina bifida, ook wel open ruggetje genoemd.

Bij een spina bifida is er bij de allereerste vorming van het zenuwstelsel een probleem opgetreden waardoor er storing is opgetreden in de vorming van het ruggenmerg, wervels en huid. Deze complexe aanlegstoornis van het zenuwstelsel leidt tot vele problemen. Die problemen strekken zich uit van continentieproblemen, problemen met het lopen, een cognitieve ontwikkelingsstoornis, waterhoofd en rugproblemen. Door de diversiteit van de problemen is de zorg voor deze kinderen bij uitstek multidisciplinair.

In het afgelopen jaar is de diagnostiek voor deze kinderen in Maastricht gestandaardiseerd met als doel om het opsporen van complicaties tijdens het opgroeien eerder op te sporen. Met behulp van de eerder genoemde gangbeeld laboratoria kunnen wij problemen beter duiden en kunnen plannen voor behandeling beter onderbouwd worden. We hopen in de komende jaren beter zicht te krijgen op de effecten van correctieve ingrepen van het ruggenmerg. Cohort studies met lange follow up met gebruikmaking van de gangbeeld laboratoria lijkt de beste methode voor evaluatie van zorg bij deze complexe patiëntengroep.

De zorg en diagnostiek rond de spina bifida heeft een grote verandering ondergaan. Sinds 1 januari 2006 worden bij alle zwangeren een echo-scopisch onderzoek aangeboden rond twintig weken zwangerschap. 
Dit onderzoek leidt in de meeste gevallen tot een vroege diagnose van de spina bifida. Vaak wordt gekozen voor afbreking van de zwangerschap. Met als gevolg dat er een landelijke afname is van het aantal kinderen dat wordt geboren met een spina bifida. Hoewel er een groep ouders is, die om religieuze redenen afziet van zwangerschapsafbreking. Milde afwijkingen in de vorm van spina bifida occulta worden regelmatig niet op de echo gezien en pas na de geboorte ontdekt.

Het aantal kinderen met een spina bifida occulta is daarom vrijwel gelijk gebleven.

De behoefte aan deze complexe zorg blijft dus. Maastricht heeft een uniek team waar zorgvernieuwing aan de orde is.

Ons andere belangrijke thema is epilepsie. Epilepsie heeft een enorme impact en een hoge incidentie. Het aantal nieuwe gevallen bedroeg 67 per 100.000 personen. Dat betekent dat in Nederland ongeveer 11 duizend mensen per jaar voor het eerst een epileptische aanval krijgen.

De oorzaken voor kinderen en volwassenen verschillen waarbij epilepsie bij kinderen vaker komt door beschadigingen rond de geboorte(zuurstofgebrek of een infectie), of door een genetische oorzaak. In een recente Italiaanse studie bleek $20 \%$ van de patiënten met een ernstige vroege epilepsie (in het eerste levensjaar) een genetische oorzaak te hebben. Onze samenwerking met de klinisch genetici is dus bij deze kinderen van groot belang. Samen met epilepsie centrum Kempenhaeghe vormt Maastricht UMC het Academisch Centrum voor Epileptologie (ACE).

Door de bundeling van krachten is concentratie van patiënten met complexe epilepsie een feit. Door deze concentratie van patiënten kunnen nieuwe studies naar individuele therapie op basis van de genetische eigenschappen gestart worden. Dit is slechts een voorbeeld van de mogelijkheden.

De ontwikkeling van een epilepsie monitoring unit in het MUMC+ is een grote stap in de ontwikkeling van ons centrum. Een dergelijke afdeling is cruciaal voor onze verdere ontwikkeling van epilepsie zorg en verdient een compliment voor het team, omdat hier ver over de grenzen van afdelingen is gegaan. Het opent de weg naar nieuwe behandelingen die kunnen bijdragen aan de verbetering van epilepsie zorg voor het kind.

Klassiek zijn studies bij epilepsie gericht geweest op het bereiken van aanvalsvrijheid. Op de kinderleeftijd vormen cognitieve problemen bij kinderen met epilepsie een grote bedreiging voor de school en maatschappelijke carrière. Vroege detectie van bedreigde kinderen is dan ook van het grootste belang. De studies naar cognitie aan frequent voorkomende epilepsie vormen op de kinderleeftijd zoals absence en Rolandische epilepsie zijn van groot belang vanwege de maatschappelijke impact.

Toekomstige ontwikkelingen met diepe hersen stimulatie voor ernstige epilepsie op de kinderleeftijd passen binnen academisch centrum voor epileptologie en het bijzondere aandachtsgebied neuromodulatie in het MUMC+.

Naast de hoofdthema's wil ik graag stilstaan bij onderwerpen waar de kinderneurologie van Maastricht een sterke samenwerkingspartner is. 
Een paar onderwerpen wil ik in het bijzonder noemen: de zorg en het onderzoek bij patiënten met neuromusculaire aandoeningen;

Onderzoek naar de leerproblemen bij kinderen met neurofibromatosis; de ziekte van Duchenne en myotone dystrofie; en Rolandische en Absence epilepsie. Dit onderzoek vindt plaats binnen de samenwerking tussen het MUMC+ en het centrum voor neurologische bepaalde leerstoornissen Kempenhaeghe.

Ik zie in de toekomst veel mogelijkheden om ook bij andere aandoeningen binnen de academische expertise centra aandacht te schenken aan cognitie als een belangrijke factor die de schoolse carrière en uiteindelijke mogelijkheden voor kinderen kunnen beïnvloeden.

\section{Zorg:}

Wat zou de rol van onze academische afdeling kinderneurologie moeten zijn in de organisatie van zorg.

De minister heeft met de notitie "Robijn" aangegeven wat de kaders voor zijn voor de Academische centra. Daarbij wordt gesproken van een academische patiënt als er sprake is van een hoge behandelintensiteit, wetenschap, uniek zorgaanbod, multispecialistische zorg, complexe operatie, zeldzame diagnose, dure medicatie, tertiaire verwijzing of jonge patiënten. Ik wil graag met u een paar zaken langslopen waarom kinderneurologie bij uitstek een Academische discipline is.

Het wetenschappelijke aspect is belangrijk. Hiervoor is concentratie van zorg en samenwerking noodzakelijk. We hebben meerdere multispecialistische zorg teams, ik noem een paar voorbeelden: spasticiteitsteam, spina bifidateam, epilepsiechirurgie team, neurofibromatosis team en myotone dystrofie team. Belangrijk is stil te staan bij de rol van de paramedici en de verpleegkundig specialist of nurse practitioner. In contacten met patiënten en praktische coördinatie van deze multispecialistische zorg spelen zij een cruciale rol.

Een punt van aandacht is de rol van de patiënt en ouder. Ik hoop dat we in de komende jaren patiënten en ouders meer kunnen betrekken om de zorgprocessen beter in te kunnen richten.

Het feit dat de raad van bestuur belangrijke infrastructurele projecten ondersteunt zoals de epilepsie monitoring unit, klinische gangbeeld laboratoria, inclusief het bijzondere gangbeeld lab met virtuele omgeving is heel belangrijk. De samenwerking met Kempenhaeghe door middel van het academisch centrum voor epileptologie is een belangrijke samenwerking om complexe patiënten complete diagnostiek en behandeling te kunnen aanbieden.

De complexe operatie is een ander belangrijk aspect van onze positie als academische centrum. De visie van de raad van Bestuur aandacht te richten op neuromodulatie binnen het "hersenen en zenuw centrum" heeft er toe geleidt dat Maastricht een bijzondere en unieke positie heeft.

In het Maastricht UMC+ is de zorg voor kinderen geconcentreerd op de poli voor het kind en de kinderafdelingen. Jaren geleden is al geconstateerd dat het niet alleen de kinderartsen zijn die de zorg verlenen op de afdelingen maar dat in toenemende mate zorg door en met andere specialisten wordt gedaan. In het platform voor het kind kijken we met alle betrokken zorgprofessionals, ongeacht hun specialisme samen naar optimalisatie van zorg voor het kind. 
Maar met alleen academische zorg komen we er niet. Niet complexe zorg maar specialistische zorg die iedere patiënt in zijn of haar eigen regio moeten kunnen krijgen. Met die gedachte heeft mijn voorganger professor Hans Vles een belangrijke samenwerking gestart met de niet academische ziekenhuizen in de regio.

Een vast aanspreekpunt voor dokters in de niet academische centra is van groot belang. Met consult functies in het Catharina ziekenhuis, Eindhoven, Maxima medisch centrum Veldhoven, Viecurie Venlo, Sint Jans Gasthuis Weert, Elkerliek ziekenhuis Helmond, en Laurentius ziekenhuis Roermond wordt deze samenwerking gestalte gegeven. Naar de toekomst lijkt bestendigen van dit prachtige netwerk en investeren in zorg innovaties in de vorm van videoconferentie van groot belang.

Naast de samenwerking met regionale ziekenhuizen is een afstemming met de kinderrevalidatie centra in de regio essentieel. Dit past ook binnen het landelijke beleid om te komen tot een landelijk register voor patiënten met een cerebrale parese. Hierdoor hopen ouders, patiënten en zorgverleners tot een uniforme zorgkaart in Nederland te komen. Zodat iedere patiënt de juiste en tijdige behandeling krijgt.

Een punt van zorg hierbij is het feit dat hier in Maastricht revalidatieartsen moeten gaan werken in een eigen, voor anderen niet toegankelijk patiëntendossier.

$\mathrm{Na}$ het debacle van het landelijke patiëntendossier is dit een hele zorgelijk ontwikkeling. Dit kunnen en mogen we niet accepteren in het belang van goede en veilige patiëntenzorg.

Cognitieve problemen bij kinderen op de afdeling kinderneurologie worden gezamenlijk opgepakt met collega's van de psychologie en psychiatrie in Maastricht. Maar zoals eerder aangegeven hebben wij een belangrijke steun aan het centrum voor neurologische bepaalde leerstoornissen in Kempenhaeghe.

We kunnen concluderen dat het best goed geregeld is. Het klinkt als muziek in de oren. Juist daarom wil ik aandacht schenken aan de mogelijkheden voor muziek als therapievorm. Al drie decennia geleden werd aangetoond dat het luisteren naar klassieke muziek de aandacht kon verbeteren.

Ik hoop de komende jaren samen met andere leden uit ons team muziek wat meer op de voorgrond te kunnen krijgen en te kijken hoe we de motorische en cognitieve mogelijkheden van onze patiënten op deze alternatieve wijze kunnen verbeteren.

\section{Onderwijs en opleiding:}

Als afdeling kinderneurologie participeren wij in alle fases van de medische opleiding. Maastricht heeft een uniek onderwijs profiel, waarbij probleem georiënteerd onderwijs centraal staat.

In de opleiding tot kinderarts en neuroloog hebben wij vaste en niet vaste opleidingsmomenten. Georganiseerde cursussen versus bedside teaching met afsluitende feedback. Waar probleem georiënteerd onderwijs steeds meer centraal staat in onderwijs, wordt het onderwijs aan medici steeds meer gekoppeld aan competenties. Belangrijk is bij deze competenties de belangen van patiënt en ouders in het oog te houden. Zoals ik in mijn titel heb aangegeven moeten we denken in mogelijkheden. Het perspectief in wat je wel kan is namelijk veel positiever dan het perspectief wat je allemaal niet kan. 
Het doet mij dan ook heel veel deugd dat een aantal van onze assistenten neurologie de subspecialisatie kinderneurologie zullen gaan doen. Allemaal met een eigen profiel. Deze ontwikkeling biedt naar de toekomst mogelijkheden voor bestendiging en ontwikkeling van het netwerk kinderneurologie in de regio.

De achtergrond van de Nederlandse kinderneurologen is wel bijzonder in Europees perspectief.

In Europa is kindergeneeskunde het basisspecialisme voor de kinderneurologie maar in Nederland is dat in meer dan $75 \%$ van de gevallen neurologie.

Ik hoop dat we in de komende jaren de instroom vanuit de kindergeneeskunde kunnen bevorderen om zo het gezamenlijke aspect van onze specialisatie te kunnen benadrukken.

Onderwijs samen met patiënten en hun ouders is een belangrijke stap om problemen niet alleen vanuit een medisch perspectief te brengen. Patiënten kunnen direct duidelijk maken wat een bepaalde ontwikkeling voor hen en de hele patiëntengroep kan betekenen.

Aan het begin van mijn rede heb ik u laten kennismaken met een paar van mijn patiënten met ernstige schade aan de hersenen door zuurstof gebrek of infectie. Deze kinderen lijken op het eerste gezicht alleen maar ernstige beperkingen te hebben. Maar hebben met name mogelijkheden die hen tot unieke individuen maken. 


\section{Dankwoord}

Allereerst wil ik de rector magnificus, de leden van het college van bestuur van de Universiteit Maastricht, de Raad van bestuur van het MUMC+, in het bijzonder de decaan en het college van toezicht bedanken voor het in mij gestelde vertrouwen.

Ik wil een ieder die aan mijn vorming tot kinderneuroloog en wetenschapper heeft bijdragen op deze plaats bedanken.

Professor Hans Vles. Jij hebt mij benaderd en ervan overtuigd dat Maastricht een heel mooi centrum is en vele mogelijkheden biedt. Je hebt een prachtige groep opgebouwd, stevig verankert in het Academisch ziekenhuis, de universiteit en de regio.

Het kind heeft hierbij altijd centraal gestaan!

Het is voor mij een voorrecht om hierop voort te mogen bouwen.

Het hoofd van de afdeling neurologie, Professor Robert van Oostenbrugge dank voor het warme welkom en de zeer prettige samenwerking, ik zie uit naar de komende jaren.

Mijn wetenschappelijke vorming

Beginnend als student met onderzoek naar het hart bij dr A. Vermeulen, mijn vader. Daarna definitief verder in de neurowetenschappen onder leiding van professor Harry Steinbusch. Mijn promotie team professor Hans Stoof, dr Benjamin Drukarch en Professor Erik Wolters.

Mijn opleiding

Veel dank aan mijn opleiders, professor Koetsier, professor Jan Heimans en prof.dr Bernard Uitdehaag

En in de kinderneurologie professor Marjo van der Knaap die mij gewezen heeft op de mogelijkheden in kinderneurologie en voor mij een voorbeeld is hoe je patiënt je naar onderzoek leidt en andersom.

Professor Leo Smit voor de klinische opleiding in de kinderneurologie

Professor Jules Becher die met een aanstekelijke lach mij patiënten op de mat leerde onderzoeken. En mij stimuleerde in het wetenschappelijk onderzoek bij de kinderen met cerebrale parese.

De neuroradiologen en de MR fysici voor een samenwerking op het gebied van nieuwe beeldvormende technieken, ik zie met enthousiasme de toekomst tegemoet.

Het samenwerkingsverband C-BiLLT, Joke Geytenbeek, Annemieke Buizer, en Kim Oostrom. Dit is onderzoek dat mogelijkheden van kinderen op het gebied van taal en communicatie verder brengt.

Alle promovendi en onderzoekers:

Petra van Schie, Sebastian Grunt, Inge Zonneberg, Bloeme van der Knoop, Laura Bonouvrie, Laetitia Wagener, Eric Fonseca, Emma Vaillant, Irene Moll, Sabine Fleuren en Maud Verbeek.

Alle studenten en in het bijzonder Wouter Henneman, Laurike Harlaar en Brian Martens. 
De landelijke contacten met de kinderneurologen en de leden van de werkgroep neonatale neurologie waar altijd een luisterend oor te vinden is.

De afdeling kindergeneeskunde, onze partners in de zorg voor zieke kinderen, met professor Luc Zimmermann aan het hoofd.

Dr Danilo Gavilanes, professor Boris Kramer en dr Tim Wolfs wil ik danken voor het gezamenlijk optrekken in het experimentele onderzoek.

Hierna zal ik een aantal groepen noemen, waar ik veel dank aan ben verschuldigd omdat zij onze multidisciplinaire teams mogelijk maken.

De afdeling neurochirurgie,

De afdeling fysiotherapie,

De afdeling logopedie,

De afdeling orthopedie met professor Lodewijk van Rijn aan het hoofd, en de kinderorthopeden Adhiambo Witlox en Heleen Staal.

De afdeling klinische neurofysiologie

De afdeling klinische genetica

De kinderrevalidatieartsen, in het bijzonder Lucianne Speth, als lid van onze multidisciplinaire teams.

De vakgroep bewegingswetenschappen, in het bijzonder dr Kenneth Meijer

Een speciaal woord van dank voor de samenwerking met de collega's van Kempenhaeghe, in het bijzonder de kinderneurologen en dr Jos Hendriksen.

In een ziekenhuis werken betekent samenwerken. Voor onze afdeling kinderneurologie is het essentieel dat we goede en betrouwbare partners hebben in het MUMC+ en daarbuiten. Verpleging, doktersassistentes, secretaresses. En die hebben we! Veel dank! Bijzondere dank aan Desiree Serpenti en Dan Soudant, die ons al 25 jaar ondersteunen.

Veel dank aan de staf neurologie en de arts-assistenten, voor hun support en enthousiasme om er een fantastische afdeling neurologie met een prachtige kinderneurologie van te maken.

Het team kinderneurologie Maastricht, Joost Nicolai, Sylvia Klinkenberg en Suzanne Koudijs. Het is een eer om aan het hoofd te staan van een uitstekend team met bijzondere expertises. Ik zie met plezier en veel vertrouwen uit naar onze ontwikkeling in de komende jaren.

Patiënten en hun ouders wil ik danken voor hun hulp, inspiratie en hun doorzettingsvermogen om ons als zorg professionals te stimuleren samen te zoeken naar betere behandelingsmogelijkheden.

De steun van mijn familie en mijn schoonfamilie

Mijn ouders stimuleerden mij en mijn zussen en broer op een breed gebied van school en muziek. Ze maakten ons tot een fantastisch gezin.

Mijn moeder, die helaas niet meer onder ons is, die ons alle vier stimuleerde om er alles uit te halen, resulterend in vier kinderen met een afgeronde academische titel, ze mag heel trots zijn. Mijn vader als voorbeeld van een medisch specialist met een grote passie voor patiëntenzorg en klinisch onderzoek. Mijn zus Jessica steun en toeverlaat op gebied van 
oncologie, mijn zus Muriel expert op het gebied van de oogheelkunde en mijn broer Camiel die laat zien hoe je van een gedachte een onderneming kan maken.

Ons gezin: Drie prachtige kinderen die ieder op hun eigen wijze zich ontwikkelen en daar mij cruciale vragen hebben gesteld.

Martijn die als 7-jarige constateerde dat ondanks het feit dat we in hetzelfde huis woonden, samen aten, ik niet dacht wat hij dacht....

Laura die in een winnend gedicht aangaf dat er dat er diepe gronden en gedachten speelden....

Tom die na het voorlezen vroeg, waarom zijn we hier eigenlijk op deze wereld....

Tot slot Hanneke. Met jou aan mijn zijde is het fantastisch... Ik heb gezegd 


\section{Referenties}

Azzopardi DV, Strohm B, Edwards AD, Azzopardi DV, Strohm B, Edwards AD, Dyet L, Halliday $H L$, Juszczak E, Kapellou O, Levene M, Marlow N, Porter E, Thoresen M, Whitelaw A, Brocklehurst P; TOBY Study Group.. Moderate hypothermia to treat perinatal asphyxial encephalopathy. N Engl J Med. 2009;361:1349-58.

Bonouvrié LA, Becher JG, Vles JS, Boeschoten K, Soudant D, de Groot V, van Ouwerkerk WJ, Strijers R, Foncke E, Geytenbeek J, van de Ven PM, Teernstra O, Vermeulen RJ. Intrathecal baclofen treatment in dystonic cerebral palsy: a randomized clinical trial: the IDYS trial. BMC Pediatr. 2013 Oct 28;13:175. doi: 10.1186/1471-2431-13-175.

Dermyshi E, Wang Y, Yan C, Hong W, Qiu G, Gong X, Zhang T. The "Golden Age" of Probiotics: A Systematic Review and Meta-Analysis of Randomized and Observational Studies in Preterm Infants. Neonatology. 2017;112:9-23.

Dominici N, Ivanenko YP, Cappellini G, d'Avella A, Mondì V, Cicchese M, Fabiano A, Silei T, Di Paolo A, Giannini C, Poppele RE, Lacquaniti F. Locomotor primitives in newborn babies and their development. Science. 2011:18;334:997-9.

Fiest KM, Sauro KM, Wiebe S, Patten SB, Kwon CS, Dykeman J, Pringsheim T, Lorenzetti DL, Jetté N. Prevalence and incidence of epilepsy: A systematic review and meta-analysis of international studies. Neurology. 2017;88:296-303.

Geytenbeek JJ, Oostrom KJ, Harlaar L, Becher JG, Knol DL, Barkhof F, Pinto PS, Vermeulen RJ. Language comprehension in nonspeaking children with severe cerebral palsy: Neuroanatomical substrate? Eur J Paediatr Neurol. 2015;19:510-20.

Hendriksen JG, Poysky JT, Schrans DG, Schouten EG, Aldenkamp AP, Vles JS. Psychosocial adjustment in males with Duchenne muscular dystrophy: psychometric properties and clinical utility of a parent-report questionnaire. J Pediatr Psychol. 2009;34:69-78.

Jellema RK, Ophelders DR, Zwanenburg A, Nikiforou M, Delhaas T, Andriessen P, Mays RW, Deans R, Germeraad WT, Wolfs TG, Kramer BW. Multipotent adult progenitor cells for hypoxic-ischemic injury in the preterm brain. J Neuroinflammation. 2015:23;12:241.

Klinkenberg S, Aalbers MW, Vles JS, Cornips EM, Rijkers K, Leenen L, Kessels FG, Aldenkamp AP, Majoie M. Vagus nerve stimulation in children with intractable epilepsy: a randomized controlled trial. Dev Med Child Neurol. 2012;54:855-61.

Moll I, Vles JSH, Soudant DLHM, Witlox AMA, Staal HM, Speth LAWM, Janssen-Potten YJM, Coenen M, Koudijs SM, Vermeulen RJ. Functional electrical stimulation of the ankle dorsiflexors during walking in spastic cerebral palsy: a systematic review. Dev Med Child Neurol. 2017 Aug 17. doi: 10.1111/dmcn.13501. [Epub ahead of print] 
Monbaliu E, Himmelmann K, Lin JP, Ortibus E, Bonouvrié L, Feys H, Vermeulen RJ, Dan B. Clinical presentation and management of dyskinetic cerebral palsy. Lancet Neurol.

2017;16:741-749.

Parrini E, Marini C, Mei D, Galuppi A, Cellini E, Pucatti D, Chiti L, Rutigliano D, Bianchini C, Virdò S, De Vita D, Bigoni S, Barba C, Mari F, Montomoli M, Pisano T, Rosati A; Clinical Study Group, Guerrini R. Diagnostic Targeted Resequencing in 349 Patients with Drug-Resistant Pediatric Epilepsies Identifies Causative Mutations in 30 Different Genes. Hum Mutat. 2017;38:216-225.

Thomese P.F., Schaduwkind. 2006, Uitgeverij Contact

Amsterdam, Nederland.

https://www.medischcontact.nl/nieuws/laatste-nieuws/artikel/de-ene-echo-is-de-andereniet.htm

https://www.rijksoverheid.nl/documenten/kamerstukken/2017/06/15/kamerbrief-overbestuurlijk-akkoord-plan-van-aanpak-robijn

van Haastert IC, Groenendaal F, Uiterwaal CS, Termote JU, van der Heide-Jalving M, Eijsermans MJ, Gorter JW, Helders PJ, Jongmans MJ, de Vries LS. Decreasing incidence and severity of cerebral palsy in prematurely born children. J Pediatr. 2011;159:86-91.

van der Aa NE, Verhage $\mathrm{CH}$, Groenendaal F, Vermeulen RJ, de Bode S, van Nieuwenhuizen O, de Vries LS. Neonatal neuroimaging predicts recruitment of contralesional corticospinal tracts following perinatal brain injury. Dev MedChild Neurol. 2013;55:707-12.

Vermeulen RJ, van Schie PE, Hendrikx L, Barkhof F, van Weissenbruch M, Knol DL, Pouwels PJ. Diffusion-weighted and conventional MR imaging in neonatal hypoxic ischemia: two-year follow-up study. Radiology. 2008;249:631-9.

Vidailhet M, Yelnik J, Lagrange C, Fraix V, Grabli D, Thobois S, Burbaud P, Welter ML, XieBrustolin J, Braga MC, Ardouin C, Czernecki V, Klinger H, Chabardes S, Seigneuret E, Mertens $P$, Cuny E, Navarro S, Cornu P, Benabid AL, Le Bas JF, Dormont D, Hermier M, Dujardin K, Blond S, Krystkowiak P, Destée A, Bardinet E, Agid Y, Krack P, Broussolle E, Pollak P; French SPIDY-2 Study Group. Bilateral pallidal deep brain stimulation for the treatment of patients with dystonia-choreoathetosis cerebral palsy: a prospective pilot study. Lancet Neurol. 2009;8:709-17. 